Leadership as Identity 
Also by Jackie Ford, Nancy Harding and Mark Learmonth CRITICAL PUBLIC SECTOR MANAGEMENT: A New Approach (co-edited with Graeme Currie)

Also by Nancy Harding and Mark Learmonth

UNMASKING HEALTH MANAGEMENT (edited)

Also by Nancy Harding

THE SOCIAL CONSTRUCTION OF MANAGEMENT: Texts and Identities

CONFUSED PROFESSIONALS: The Social Construction of Dementia (with Colin Palfrey) 


\section{Leadership as Identity}

Constructions and Deconstructions

Jackie Ford

Professor of Leadership and Organization Studies

Nancy Harding

Senior Lecturer in Organization Studies

Mark Learmonth

Associate Professor of Organization Theory

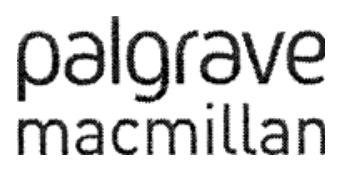




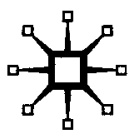

(c) Jackie Ford, Nancy Harding and Mark Learmonth 2008

Softcover reprint of the hardcover 1st edition 2008 978-0-230-51632-8

All rights reserved. No reproduction, copy or transmission of this publication may be made without written permission.

No portion of this publication may be reproduced, copied or transmitted save with written permission or in accordance with the provisions of the Copyright, Designs and Patents Act 1988, or under the terms of any licence permitting limited copying issued by the Copyright Licensing Agency, Saffron House, 6-10 Kirby Street, London EC1N 8TS.

Any person who does any unauthorized act in relation to this publication may be liable to criminal prosecution and civil claims for damages.

The authors have asserted their rights to be identified as the authors of this work in accordance with the Copyright, Designs and Patents Act 1988.

First published 2008 by PALGRAVE MACMILLAN

Palgrave Macmillan in the UK is an imprint of Macmillan Publishers Limited, registered in England, company number 785998, of Houndmills, Basingstoke, Hampshire RG21 6XS.

Palgrave Macmillan in the US is a division of St Martin's Press LLC, 175 Fifth Avenue, New York, NY 10010.

Palgrave Macmillan is the global academic imprint of the above companies and has companies and representatives throughout the world.

Palgrave ${ }^{\circledast}$ and Macmillan ${ }^{\star}$ are registered trademarks in the United States, the United Kingdom, Europe and other countries.

ISBN 978-1-349-35442-9 ISBN 978-0-230-58418-1 (eBook)

DOI $10.1057 / 9780230584181$

This book is printed on paper suitable for recycling and made from fully managed and sustained forest sources. Logging, pulping and manufacturing processes are expected to conform to the environmental regulations of the country of origin.

A catalogue record for this book is available from the British Library.

A catalog record for this book is avaitable from the Library of Congress.

$\begin{array}{llllllllll}10 & 9 & 8 & 7 & 6 & 5 & 4 & 3 & 2 & 1\end{array}$

$\begin{array}{llllllllll}17 & 16 & 15 & 14 & 13 & 12 & 11 & 10 & 09 & 08\end{array}$

Transferred to Digtal Printing 2011. 
Jackie Ford dedicates this book to Chris, Claire and Mikey.

Nancy Harding dedicates it to Brychan James Harding and Dylan Thomas Harding.

Mark Learmonth dedicates it to Glynis, James and Katie. 


\section{Contents}

List of Table viii

Acknowledgements ix

Part I Constructions

1 Texts 9

2 Leadership as Performative: Or How the Words 'Leader' and 'Leadership' Do Things 32

3 The Leader as Hero 51

4 Learning to be a Leader-Training Courses 68

Closing Notes to Part I $\quad 86$

Part II Deconstructions

5 Queer(y)ing Leadership $\quad 91$

6 Gendering Leadership 116

7 The Psyche and Leadership 139

Closing Notes to Part II 162

Part III Towards Emancipatory Leadership Development?

8 Conclusions: Towards Emancipatory Leadership? 167

$\begin{array}{ll}\text { References } & 185\end{array}$

$\begin{array}{ll}\text { Index } & 201\end{array}$ 


\section{Table}

Table 4.1 Definitions of Leadership 


\section{Acknowledgements}

Earlier versions of several chapters have appeared elsewhere, as follows:

Chapter 2: Leadership As Performative: Or How The Words 'Leader' and 'Leadership' Do Things

Learmonth, M. 2005. Doing things with words: the case of 'management' and 'administration'. Public Administration 83, 3, 617-37.

Chapter 3: The Leader as Hero

Learmonth, M. (2001) NHS Trust Chief Executives as Heroes? Health Care Analysis 9 (4) 417-36.

Chapter 4: Learning to be a Leader - Training Courses

Ford, Jackie and Harding, Nancy. (2007) 'Move Over Management:

We're all Leaders Now.' Management Learning 38, 5, 475-93.

Chapter 6: Gendering Leadership

Ford, Jackie. (2007) 'Managers As Leaders: Towards A Post-Structuralist Feminist Analysis Of Leadership Dynamics In UK Local Government', Unpublished PhD thesis.

Chapter 7: The Psyche and Leadership

Ford, Jackie and Harding, Nancy. Leadership Theory: A Promise of Happiness and Goodness or a Threat of Sado-Machochism? Paper presented at Academy of Management Conference, Philadelphia, August 2007, and submitted to Organization Studies September 2007. 